Trikonomika

Volume 18, No. 2, December 2019, Page. 54-61

ISSN 1411-514X (print) / ISSN 2355-7737 (online)

\title{
MIMICRY MARKETING STRATEGY (MMS) ON MARKETING PERFORMANCE: THE ROLE OF BUSINESS ENVIRONMENT AND TYPES OF INDUSTRY
}

\author{
Suliyanto \\ suli_yanto@yahoo.com \\ Ary Yunanto \\ Economics and Business Faculty, Jenderal Soedirman University \\ Jl. Prof. Dr. H.R. Boenyamin No.708, Grendeng, Dukuhbandong, Grendeng, \\ Kec. Purwokerto Utara, Kabupaten Banyumas, Jawa Tengah 53122
}

received: 17/6/19; revised: 24/8/19; published: 31/12/19

\begin{abstract}
Research about Mimicry Marketing Strategy (MMS) on marketing performance has been done before. However, in the previous study, there was no separation between the service industry and the manufacturing industry. In addition, there was also no experiment in the business environment with intense competition and business environment with non-intense competition. This study aims to analyze the effects of MMS on marketing performance in the service industry and manufacturing industry with intense and non-intense business environment. Respondents in this study were 100 MSMEs in Banyumas Regency, taken using Random Sampling method. The analytical tool used in this study is multiple regression analysis and regression analysis moderating sub-groups with a Chow-test. The results of this study indicate that mimicry towards consumers, mimicry towards competitors, and mimicry toward suppliers have positive effect on marketing performance, while mimicry on intermediaries does not have a positive effect on marketing performance, business environment and types of industry moderate the relationship between MMS and marketing performance.
\end{abstract}

Keywords: mimicry marketing strategy; marketing performance; business environment; types of industry

\section{INTRODUCTION}

Contingency theory explains the relationship between the suitability of the strategy and the environment, in which the appropriate strategies which are fit to the environment will lead to satisfying organizational performance (Lee and Miller, 1996). Mimicry Marketing Strategy (MMS) is one of the strategies to adapt to the business environment, competitors, suppliers, intermediaries, and consumers (Suliyanto, 2015). Previous research about MMS on marketing performance has proven that mimicry towards consumers and mimicry towards competitors have positive effect on the quality of relationships with partners and innovation, while the quality of relationships with partners and innovation has a positive effect on marketing performance (Suliyanto, 2015). However, in that previous study, there was no separation between the service industry and the manufacturing industry. Furthermore, there was also no separation between industries that had intense competition and industries that had non-intense competition.
This study examines MMS as an antecedent of marketing performance by placing environmental factors and types of industry as moderation. Research that examines the antecedents of organizational performance will always be interesting. Performance is often identified with efficiency and effectiveness (Neely et al., 1995). Organizational performance is related to how well the organization achieves marketing objectives and also financial goals (Yamin et al, 1999; Li et al, 2006). Organizational performance in previous research is generally measured using financial and marketing criteria, which consists of return on investment (ROI), market share, profit margin, the growth of ROI, the growth of sales, and the growth of market share (Pulendran et al, 2000). Manager's assessment of marketing performance is important both about the content and its consequences (Clark, 2000). Marketing performance shows the ability of an organization to transform itself in facing challenges from the environment with a long-term perspective (Keats et.al, 1988). Marketing performance measurement can be done by using objective and subjective approaches. 
In this study, performance measurement which is used is subjective measurement because the subjects of this study are MSME managers, in which, in MSME, the objective marketing performance data is very limited.

Interdependence theory states that the organization's success or failure is very dependent on the ability of the organization to adjust to the challenge of the environment, such as the level of competition and applicable regulations (Caroll and Hannan, 1989). The ability to adapt to the environment will have a positive effect on performance (McKee, et al., 1989). This is supported by the research of Hessket and Kotler (1992) which stated that a strong and adaptive culture has strength and a real contribution to improve organizational performance. Yamin et al. (1999) also stated that adaptability has a positive influence on resource productivity. This is supported by the opinion of Switala et al. (2018) which stated that adaptability to logistics service providers has a positive effect on performance. Luo (1999) who conducted research studies on small industries in China concluded that adaptability has a relationship with performance in small scale businesses. In the individual context, Spiro and Weitz (1990) stated that sales adaptability will increase sales effectiveness. Furthermore, Dess et al., (1997) stated that one of the indicators of organizations that have adaptability to the environment is in the product and business planning process involving customers, suppliers and fund providers. MMS is one of the strategies to adapt to the business environment, competitors, suppliers, intermediaries, and consumers (Suliyanto, 2015).

Adaptation capability will improve overall organizational performance (Mentzer et al., 2000). Competitive advantages can lead to high levels of economic performance, customer satisfaction and loyalty, and relationship effectiveness (Lakhal, 2009). Miller and Friesen (1983) stated that organizational adaptability is closely related to the level of innovation, willingness to take risks, and proactive strategy orientation, whereas Jenssen (2003) stated that increasing total capability and innovation will increase the distinctiveness of competitive advantages that are difficult to be copied. Bharadwaj et al., (1993) suggested that the company ability to continue innovate its products would keep the product in accordance with the wishes and needs of the customers. Walton et al., (2008) stated that companies that can adapt to their partners' cultures will be able to improve the quality of relationships and increase trust so that they will ultimately increase commitment. Walter and Ritter (2003) mentioned that adaptation, trust, and commitment have influence on the relationships of consumers and suppliers. Morgan and Hunt (1994) stated that marketing relations will increase competitive advantage. Kevin (2003) in his survey of the car industry found that companies that have good relationships will have superior advantages and become highly competitive. Based on the literature review, it shows that marketing performance is influenced by competitive advantage, while competitive advantage is influenced by the adaptation ability of the organization.

Research on MMS that separates service industries and manufacturing industries is important because the business environment conditions between service industries and manufacturing industries are different. In general, technological developments in the service industry are more dynamic compared to technological developments in the manufacturing industry, besides that market preference in the service industry are also change faster compared to the manufacturing industry. By conducting research that distinguishes MMS degrees between companies in the service industry and in the manufacturing industry, the right marketing strategies can be formulated for companies in those two different types of industries.

This study tries to include environment as a moderating variable between MMS and marketing performance. It needs to be done because in essence, this strategy is the way to adapt to environmental changes. This is in accordance with the statement of Luo, (1999), which stated that the suitability of strategy orientation with the environment will affect organizational performance, the same thing also expressed by Spiro and Weitz (1990), which stated that organizational adaptability is an important variable in achieving organizational performance so that the environment is seen as an important factor that determines the effectiveness of MMS. Today's competitive business environment requires effective marketing strategies to achieve their market and financial goals (Pimenta da Gama, A. 2011). With the inclusion of environment as a moderating variable, different effects of MMS in different environmental conditions can be determined, and in which environmental condition MMS is more effective to be applied.

Micro, Small and Medium Enterprises (MSMEs) play a very important role for the Indonesian economy. It can be seen from the large contribution of MSMEs to GDP in 2018 which reached 60.34 percent and was able to absorb employment reaching 97.22 percent (Ministry of Industry, 2019) . But MSMEs generally still face marketing problems. An intense business environment and adaptability to the environment can affect the marketing performance of MSMEs. This study aims to analyze the differences in the degree of MMS of service industries and manufacturing industries. In addition, another purpose ofthis research is to analyze environmental factors as moderating variables of the causal relationship between the dimensions of MMS and marketing performance. It is expected that MSMEs can compete with competitors by implementing MMS.

Based on previous research, the hypothesis can be formulated as follows: (a) MMS toward consumers has a positive effect on marketing performance; (b) 
MMS toward competitors has a positive effect on marketing performance; (c) MMS toward suppliers has a positive effect on marketing performance; (d) MMS toward intermediaries has a positive effect on marketing performance.

The business environment moderates the relationship between MMS and marketing performance. The business type moderates the relationship between MMS and marketing performance.

\section{METHOD}

This research was conducted in Banyumas Regency. Subects of the research are MSME entrepreneurs who produce superior products in Banyumas Regency. Primary data in the form of respondents' responses about mimicry strategies towards: consumers, competitors, suppliers, intermediaries, business environment, and marketing performance. Primary data was collected through surveys and interviews with MSME entrepreneurs and Disperindagkop Banyumas Regency. The sample size in this study was 100 respondents, while the sampling technique used was random sampling, with target population of MSME entrepreneurs who have run their business for more than five years. Secondary data was obtained from sources such as the Central Bureau of Statistics (Badan Pusat Statistik) and Disperindagkop of Banyumas Regency.

The MMS degree of service industries and MMS degrees in manufacturing industries is measured using descriptive statistical analysis. To analyze the influence of MMS on the marketing performance of MSMEs with environment as moderating variables used multiple regression analysis and moderating regression analysis using sub groups, with the Chow test, the formula as follows:

$$
F=\frac{(R S S r-R S S u r) / k}{(R S S u r) /(n 1+n 2-2 k)}
$$

In which RSSr is the restricted residual sum of square, while RSSur is the total of the sample residual sum of square in the first group (RSS1) and the sample residual sum of square in the second group (RSS2). Variables are stated to moderate if $\mathrm{F}$ count $>\mathrm{F}$ table with $\mathrm{df}=(\alpha ; \mathrm{k} ; \mathrm{n} 1+\mathrm{n} 2-2 \mathrm{k})$.

\section{RESULT AND DISCUSSION}

Distribution of characteristics are based on business types, namely services and manufacturing business. The purpose of this grouping is to see the difference in results.

Based on Table 1, from 100 respondents, there are $50.00 \%$ of respondents from the service industry and there are $50.00 \%$ of respondents from the manufacturing industry. The percentage of survey results use the same number because researchers deliberately collected the number of respondents each industry $50 \%$ in order to avoid data gap between the service industry and the manufacturing industry. Respondents based on age were dominated by the age of 20-30 year-old as much as $36.00 \%$ because the age of $20-30$ year-old is the most productive age so that the entrepreneurial spirit is quite high. The grouping of respondents based on gender is dominated by men as much as $62 \%$ while for women entrepreneurs as much as $37 \%$. This is because men have obligation to make a living in rural areas, while women take care of the household more. Based on the level of education, it is dominated by high school graduates and Associate/Bachelor/Master Degree, which is $41 \%$ each. It happens because people who have an entrepreneurial orientation are those who are from high school and Associate/Bachelor/Master Degree, while those with lower education level are more oriented to be workers or laborers.

Validity test is used to measure the ability of an indicator to measure variables. The validity test of this study using the product moment correlation formula by comparing the value of $r$ is counted by $r$ table at a validity level of $95 \%$.

The validity test was carried out on a pilot sample of 30 so that $\mathrm{df}=30-2=28$ with a one-sided test. In the product moment table, $r$ table is 0.361 . Based on the calculation results, it can be seen that all values of $r$ count $>0.3611$, so it can be concluded that all indicators of the variable mimicry toward consumers, mimicry toward competitors, mimicry toward suppliers, mimicry toward intermediaries, business environment and marketing performance are valid and can be used as research instrument.

The reliability test in this study was measured by Cronbanch alpha statistical test. Questionnaires are reliable if Cronbanch alpha $>0.60$. Reliability test which was carried out include the variables; mimicry toward consumers, mimicry toward competitors, mimicry toward suppliers, mimicry toward intermediaries, innovation, relationship quality, and marketing performance. The complete test results are explained in Table 2.

Based on Table 2, the questionnaire reliability test's result is known that Cronbach's Alpha from variable mimicry toward consumers, mimicry toward competitors, mimicry toward suppliers, mimicry toward intermediaries, business environment and marketing performance $>0.60$, so it can be concluded that each indicator or question in all variables used is reliable and can be used as the research instruments.

Multiple regression analysis is used to determine the effect of MMS variables which consist of mimicry toward consumers, mimicry toward competitors, mimicry toward suppliers, mimicry toward intermediaries, business environment and marketing performance (Table 3). 
Based on the results of the multiple regression analysis as a whole, it can be concluded that the variable mimicry towards consumers, mimicry towards competitors, mimicry towards suppliers, has a positive effect on marketing performance. However, mimicry toward intermediaries does not affect marketing performance. R Square value of 0.557 , it means that $55.7 \%$ of marketing performance can be explained by the variable mimicry towards consumers, mimicry towards competitors, mimicry towards suppliers, and mimicry towards intermediaries. The model accuracy test shows the value of $F$ count $=29,818$ with a significance of 0,000 $<0,05$. It shows that the regression equivalence is fit.

The results of this study support the previous research (Suliyanto, 2015) which stated that mimicry towards consumers and mimicry towards competitors have a positive effect on the quality of relationships with partners, while the quality of relationships with partners and innovation factors have a positive effect on marketing performance. The results of this study also support the research of (Caroll and Hannan, 1989; McKee, et al., 1989; Switala et al., 2018; Luo 1999), which stated that adaptability has a positive effect on organizational performance. At the individual level, this research supports the research of Spiro and Weitz (1990) which stated that sales person adaptability has a positive effect on salesperson performance, because MMS is a form of adaptability.

Business environment is a supporting factor for the success of MSMEs in Banyumas Regency. MSMEs in Banyumas is expossed to market changes and fast changes in business environment. To be able to maintain his or her business, the business actor must be able to adjust his or her business with every change that occurs. The analysis of this study focuses on indicators of technological turbulence, intensity of competitors, and changes in market prefrences. The following are the differences in the results of MMS regression analysis in the intense business environment and non-intense business environment.

Based on the results of multiple regression analysis that is separated into two, intense business environment and non-intense business environment, it was concluded that in intense business environment, the mimicry variable toward competitors has a positive effect on marketing performance, while mimicry towards consumers, mimicry towards suppliers, and mimicry towards intermediaries do not have a positive effect on marketing performance. On the other hand, in nonintense business environment, it was concluded that the mimicry variable towards consumers has a positive effect on marketing performance, whereas mimicry towards competitors, mimicry towards suppliers, and mimicry toward intermediaries do not have a positive effect on marketing performance.

The value of $\mathrm{R}$ Square in intense business environment is at 0.478 , while Value R Square in non- intense business environment is at 0.392 . It shows that MMS's contribution to marketing performance in companies with intense business environment is greater compared to MMS's contribution to marketing performance in companies with non-intense business environment (Table 4).

The results of statistical calculations show the $\mathrm{F}$ value of statistics in intense business environment is 12,379 , while the $F$ value of statistics in non-intense business environment is 5,808 , with a significance of $0,000<0,05$. It shows that the two regression equivalences formed are fit.

Based on the results of the analysis using the chowtest, the statistical $\mathrm{F}$ value is 10,834 , while the $\mathrm{F}$ table is 3,091 . Because the $F$ value of statistics $(10,664)>$ F table $(3,091)$, it can be concluded that the business environment moderates the relationship between MMS strategies toward marketing performance. The results of this study support the research which was conducted by Han, et al., (1998; Pulendran (1996); Appiah-Adu (1998), Greenley (1995), it stated that the business environment moderates the relationship between market orientation and marketing performance. The market orientation is a culture to adapt to meet the customers' needs and preferences and adjust to the competitor's strategy. The adjustment to the consumers' needs and preferences and the adjustments to competitors' strategies are forms of adaptability that are in line with the MMS concept.

MSMEs in Banyumas Regency consist of various types of businesses. To see the difference that occurs if MMS is applied to the type of business, the researchers took two types of samples. They are services and manufacturing business. The following are the results of multiple regression analysis based on the type of business.

Based on the results of multiple regression analysis that is separated into the service industry and manufacturing industry, it is concluded that in the service industry, the variable mimicry toward consumers has a positive effect on marketing performance, while mimicry toward competitors, mimicry toward suppliers, and mimicry toward intermediaries do not have a positive effect on marketing performance. In the manufacturing industry, it is concluded that the mimicry variable toward competitors has a positive effect on marketing performance, while mimicry toward consumers, mimicry toward suppliers, and mimicry toward intermediaries have no positive effect on marketing performance.

The value of R Square in the service industry is 0749, while the R Square value in the manufacturing industry is 0.369 . This shows that MMS's contribution to marketing performance in companies from service industries is greater than MMS's contribution to marketing performance in companies from manufacturing industries (Table 5). 
The results of statistical calculations show that the $\mathrm{F}$ value of statistics in the service industry is 33,650 , while the statistical $\mathrm{F}$ value in the manufacturing industry is 6,659 , with a significance of $0,000<0,05$. It shows that the two regression equivalences formed are fit.

Based on the chow-test, the $F$ value of statistics is 12,984 , while the F table is 3,091 . Because of the $F$ value of statistics $(12,984)>F$ table $(3,091)$, it can be concluded that the type of business moderates the relationship between MMS to marketing performance. The factors that distinguish the service industry and manufacturing industry are the technology and market turbelences, in which technology turbelence and market turbelence in the service industry are higher than in the manufacturing industry. As a result, this study indirectly supports Appiah-Adu's (1998) research; Diamantopoulos and Hart, (1993); Harris, (2001); Pulendran, (1996), which stated that market turbulence moderates the relationship between market orientation and marketing performance and it also supports Rose and Shoham's (2002) research which stated that technological turbulence moderates the relationship between market orientation and marketing performance, in which market orientation is a form of adaptability, which is the same as MMS.

\section{CONCLUSION}

Based on the above analysis, conclusions can be formulated as follows: (1) Mimicry toward consumers, mimicry toward competitors, and mimicry toward suppliers have positive effect on marketing performance, while mimicry toward intermediaries does not have a positive effect on marketing performance; (2) Business environment moderates the relationship between MMS and marketing performance; (3) Types of business moderate the relationship between MMS and marketing performance.

To improve the marketing performance, it is necessary to make efforts to increase mimicry towards consumers by increasing the ability to analyze consumer's character appropriately, improving the ability to analyze consumer's conditions appropriately, increasing the ability to place themselves in the position of consumers emotionally, always doing experiment with various marketing approach, improving the ability to use different marketing approach for each consumer character, as well as improving the ability to use a different marketing approach in each of the different conditions of consumers.

To improve the marketing performance, it is necessary to make efforts to increase mimicry toward competitors by increasing the ability to analyze the competitor's character appropriately, improving the ability to analyze competitors' conditions appropriately, improving marketing ability to place themselves in the position of competitors emotionally, always doing experiment to create market demand that not yet or not even been glimpsed by competitors, and increasing the ability to do co-creation with competitors to serve the same consumers.

To improve the marketing performance, it is necessary to make efforts to increase the mimicry toward suppliers by increasing the ability to analyze the character of suppliers appropriately, analyzing supplier's conditions (finance, production capacity, and supplier's experience), increasing the ability to place themselves in supplier's position emotionally, increasing capacity in creating supplier dependence on the company (the company is important to suppliers), increasing the ability to strengthen relationships with suppliers by maintaining commitment and willing to share information about new products, promotional programs, adding employees, etc. that are not confidential).

Companies that are engaged in services industry should implement MMS more compared to manufacturing companies because the marketing services company mimicry is more influential than the manufacturing company.

Companies in service industry with intense business environment should apply MMS more than companies that have non-intense business environment because in the companies that have non-intense business environment, MMS are more influential than in manufacturing companies.

The limitations of this research are firstly, the division of the business environment is not based on the level at which the business environment really faces intense competition and non-intense business environment. Secondly, the business environments are divided into two categories based on the respondent's average answer, below average or above or equal to the average. Therefore, future studies should be conducted by choosing industries that have intense competition and industries that do not have intense competition (industries that tend to be monopolistic).

\section{ACKNOWLEDGEMENTS}

Thank you for the Institute of Research and Community Service (LPPM) of Jenderal Soedirman University who support this research financially through the Professor's Special Task Facilitation and also thank you for all colleagues at the Research Center of the Faculty of Economics and Business who gave contributions in completing this research.

\section{REFERENCES}

Appiah-Adu, K. 1998. Market orientation and performance: empirical tests in a transition economy. Journal of Strategic Marketing, 6(1), 25-45.

Bharadwaj, S. G., Varadarajan, P. R., \& Fahy, J. 1993. Sustainable competitive advantage in service 
industries: a conceptual model and research propositions. Journal of marketing, 57(4), 83-99.

Carroll, G. R., \& Hannan, M. T. 1989. On using institutional theory in studying organizational populations. American Sociological Review, 54(4), 545-548.

Clark, B. H. 2000. Managerial perceptions of marketing performance: efficiency, adaptability, effectiveness and satisfaction. Journal of Strategic Marketing, 8(1), 3-25.

Dess, G. G., Lumpkin, G. T., \& Covin, J. G. 1997. Entrepreneurial strategy making and firm performance: Tests of contingency and configurational models. Strategic management journal, 18(9), 677-695.

Diamantopoulos, A., \& Hart, S. 1993. Linking market orientation and company performance: preliminary evidence on Kohli and Jaworski's framework. Journal of strategic marketing, 1(2), 93-121.

Greenley, G. E. 1995. Market orientation and company performance: empirical evidence from UK companies. British journal of management, 6(1), 1-13.

Han, J. K., Kim, N., \& Srivastava, R. K. 1998. Market orientation and organizational performance: is innovation a missing link?. Journal of marketing, 62(4), 30-45.

Harris, L. C. 2001. Market orientation and performance: objective and subjective empirical evidence from UK companies. Journal of Management studies, $38(1), 17-43$.

Jenssen, J. I. 2003. Innovation, capabilities and competitive advantage in Norwegian shipping. Maritime Policy \& Management, 30(2), 93-106.

Keats, B. W., \& Hitt, M. A. 1988. A causal model of linkages among environmental dimensions, macro organizational characteristics, and performance. Academy of management journal, 31(3), 570-598.

Kevin, Jost. 2003. Relationship and Competitive advantage. Automotive Engineering International. Warrendale. 111(6): 4-

Kotler, P. John, dan Heskett, L. James. 1992. Corporate Culture and Performance.

Lakhal, L. 2009. Impact of quality on competitive advantage and organizational performance. Journal of the Operational Research Society, 60(5), 637-645.

Lee, J., \& Miller, D. 1996. Strategy, environment and performance in two technological contexts: contingency theory in Korea. Organization Studies, 17(5), 729-750.

Li, S., Ragu-Nathan, B., Ragu-Nathan, T. S., \& Rao, S. S. 2006. The impact of supply chain management practices on competitive advantage and organizational performance. Omega, 34(2), 107-124.

Luo, Y. 1999. Environment-strategy-performance relations in small businesses in China: A case of township and village enterprises in southern China.
Journal of Small Business Management, 37(1), 37. McKee, D. O., Varadarajan, P. R., \& Pride, W. M. 1989. Strategic adaptability and firm performance: a market-contingent perspective. Journal of Marketing, 53(3), 21-35.

Mentzer, J. T., Min, S., \& Zacharia, Z. G. 2000. The nature of interfirm partnering in supply chain management. Journal of retailing, 76(4), 549-568.

Miller, D., \& Friesen, P. H. 1983. Strategy-making and environment: the third link. Strategic management journal, 4(3), 221-235.

Morgan, Robert M., and Shelby D. Hunt. 1994. The commitment-trust theory of relationship marketing. Journal of marketing 58, no.: 20-38.

Neely, A., Gregory, M. and Platts, K. 1995. Performance measurement system design: a literature review and research agenda, International Journal of Operations and Performance Management, 15(4), 80-116

Pimenta da Gama, A. 2011. An expanded model of marketing performance. Marketing Intelligence \& Planning, 29(7), 643-661.

Pulendran, S. 1996. Marketing Planning, Market Orientation and Performance: An Empirical Study of Practices in Australian Organisations (Doctoral dissertation, University of Melbourne).

Pulendran, S., Speed, R., \& Widing, R. E. 2000. The antecedents and consequences of market orientation in Australia. Australian journal of management, 25(2), 119-143.

Rose, G. M., \& Shoham, A. 2002. Export performance and market orientation: establishing an empirical link. Journal of Business Research, 55(3), 217-225.

Spiro, R and Weitz, B. 1990. Adaptive Selling: Conceptualization Measurement and Nomiligical Validity. Journal of Marketing Research. Vol. 27 (February). pp. 61-69.

Suliyanto, S., 2015. Mimicry Marketing Strategy on Marketing Performance of Small and Medium Enterprise. TRIKONOMIKA, 14(2), pp.96-103.

Świtała, M., Niestrój, K., \& Hanus, P. 2018. Examining how logistics service providers $\backslash$ 'adaptability impacts logistics outsourcing performance, customers \'satisfaction and loyalty. LogForum, 14.

Walter,A., \& Ritter, T. 2003. The influence of adaptations, trust, and commitment on value-creating functions of customer relationships. Journal of Business \& Industrial Marketing, 18(4/5), 353-365.

Walton, J. R., Salazar, R. J., \& Wang, J. 2008. The effects of adaptation, commitment and trust in crosscultural marketing relationships. Journal of Applied Business Research, 24(3), 29-38.

Yamin, S., Gunasekaran, A., \& Mavondo, F. T. 1999. REFEREED PAPERS-Relationship between generic strategies, competitive advantage and organizational performance: An empirical analysisThe results of empirical research suggests that there are. Technovation, 19(8), 507-518. 
Table 1. Profile of Respondents based on Business types, Age, Gender, and Education Level

\begin{tabular}{|c|c|c|}
\hline \multicolumn{3}{|c|}{ Based on Business Types } \\
\hline & $\begin{array}{c}\text { Total of } \\
\text { Respondents }\end{array}$ & Percentage $(\%)$ \\
\hline Service & 50 & 50,00 \\
\hline Manufacture & 50 & 50,00 \\
\hline \multicolumn{3}{|l|}{ Based on Age } \\
\hline Age (year-old) & $\begin{array}{c}\text { Age of } \\
\text { Respondents (\%) }\end{array}$ & $\begin{array}{c}\text { Age of business } \\
(\%)\end{array}$ \\
\hline$<19$ & 2,00 & 3,96 \\
\hline $20-30$ & 36,00 & 6,67 \\
\hline $31-40$ & 26,00 & 9,72 \\
\hline $41-50$ & 18,00 & 13,75 \\
\hline$>50$ & 18,00 & 25,16 \\
\hline \multicolumn{3}{|l|}{ Based on Gender } \\
\hline Gender & Total Respondents & Percentage $(\%)$ \\
\hline Men & 62 & 62,00 \\
\hline Women & 38 & 37,00 \\
\hline \multicolumn{3}{|c|}{ Based on Education Level } \\
\hline The Last Education & $\begin{array}{c}\text { Total of } \\
\text { Respondents }\end{array}$ & Percentage $(\%)$ \\
\hline Elementary School & 6 & 6,00 \\
\hline Junior High School & 12 & 12,00 \\
\hline Senior High School & 41 & 41,00 \\
\hline $\begin{array}{l}\text { Associate/Bachelor/ } \\
\text { Master Degree }\end{array}$ & 41 & 41,00 \\
\hline
\end{tabular}

Table 2. The Result of Questionnaire Reliability Test

\begin{tabular}{lccc}
\hline \multicolumn{1}{c}{ Variable } & $\begin{array}{c}\text { Cronbach's } \\
\text { Alpha }\end{array}$ & r table & Result \\
\hline Mimicry toward consumers & 0,895 & 0,600 & Reliable \\
Mimicry toward competitors & 0,815 & 0,600 & Reliable \\
Mimicry toward suppliers & 0,902 & 0,600 & Reliable \\
Mimicry towards intermediaries & 0,960 & 0,600 & Reliable \\
Business Environment & 0,798 & 0,600 & Reliable \\
Marketing Performance & 0,932 & 0,600 & Reliable \\
\hline
\end{tabular}

Table 3. Multiple Regression Analyisis based on Business Environment Intensity

\begin{tabular}{llrrrr}
\hline No & \multicolumn{1}{c}{ Variable } & Coefisien & Beta & T count & Sig \\
\hline 1. & Constants & 2,648 & & 1,064 & 0,290 \\
2. & M.Consumers & 0,209 & 0,269 & 2,480 & $0,015^{*}$ \\
3. & M.Competitors & 0,265 & 0,284 & 2,501 & $0,014^{*}$ \\
4. & M.Suppliers & 0,177 & 0,201 & 2,160 & $0,033^{*}$ \\
5. & M. Intermediaries & 0,067 & 0,115 & 1,167 & 2,246 \\
\hline & R Square & 0,557 & & & \\
& R adj. & 0,538 & & & \\
& F count & 29.818 & & & 0,000 \\
\hline
\end{tabular}

Table 4. Multiple Regression Analysis Based on Business Environment Intensity

\begin{tabular}{|c|c|c|c|c|c|c|c|c|c|c|}
\hline \multirow[b]{2}{*}{ No } & \multirow[b]{2}{*}{ Variable } & \multicolumn{4}{|c|}{ Intense Business Environment } & \multicolumn{4}{|c|}{ Non-intense Business Environment } & \multirow[t]{2}{*}{ Result } \\
\hline & & Coefisien & Beta & $\mathrm{T}$ count & Sig & Coefisien & Beta & $\mathrm{T}$ count & Sig & \\
\hline 1. & Constants & 5,041 & & 1,137 & 0,261 & 10,728 & & 3,054 & 0,004 & \\
\hline 2. & M.Consumers & 0,055 & 0,057 & 0,371 & 0,712 & 0,217 & 0,409 & 2,147 & $0,039^{*}$ & Different \\
\hline 3. & M.Competitors & 0,532 & 0,544 & 3,385 & $0,001 *$ & $-0,087$ & $-0,110$ & $-0,635$ & 0,529 & Different \\
\hline 4. & M.Suppliers & 0,103 & 0,112 & 0,901 & 0,372 & 0,136 & 0,195 & 1,263 & 0,215 & Same \\
\hline \multirow[t]{4}{*}{5.} & M. Intermediaries & 0,031 & 0,056 & 0,465 & 0,644 & 0,108 & 0,236 & 1,221 & 0,230 & Same \\
\hline & R Square & 0,478 & & & & R Square & 0,392 & & & \\
\hline & $\mathrm{R}$ adj. & 0,440 & & & & R adj. & 0,325 & & & \\
\hline & F count & 12.379 & & & 0,000 & F count & 5,808 & & 0,001 & \\
\hline
\end{tabular}


Table 5. Multiple Regression Analysis Based on Types of Industry

\begin{tabular}{|c|c|c|c|c|c|c|c|c|c|c|}
\hline \multirow[b]{2}{*}{ No } & \multirow[b]{2}{*}{ Variable } & \multicolumn{4}{|c|}{ Service Industry } & \multicolumn{4}{|c|}{ Manufacturing Industry } & \multirow[t]{2}{*}{ Result } \\
\hline & & Coefisien & Beta & $\mathrm{T}$ count & Sig & Coefisien & Beta & $\mathrm{T}$ count & Sig & \\
\hline 1. & Constants & $-1,578$ & & $-0,537$ & 0,594 & 8,961 & & 2,514 & 0,016 & \\
\hline 2. & M.Consumers & 0,464 & 0,513 & 3,831 & $0,000^{*}$ & 0,134 & 0,228 & 1,283 & 0,206 & Different \\
\hline 3. & M.Competitors & 0,247 & 0,252 & 1,770 & 0,084 & 0,305 & 0,394 & 2,216 & $0,032^{*}$ & Different \\
\hline 4. & M.Suppliers & 0,005 & 0,005 & 0,034 & 0,973 & 0,099 & 0,136 & 0,990 & 0,328 & Same \\
\hline \multirow[t]{4}{*}{5.} & M. Intermediaries & 0,109 & 0,171 & 0,171 & 0,185 & $-0,032$ & $-0,64$ & $-0,394$ & 0,695 & Same \\
\hline & R Square & 0,749 & & & & R Square & 0,369 & & & \\
\hline & $\mathrm{R}$ adj. & 0,727 & & & & R2 adj. & 0,313 & & & \\
\hline & F count & 33,650 & & & 0,000 & F count & 6,569 & & 0,000 & \\
\hline
\end{tabular}

